\title{
ARTIKELEN
}

\section{Etnisch profileren door de overheid en de zoek- tocht naar adequate remedies}

\author{
Peter Rodrigues \& Maartje van der Woude
}

\section{Inleiding}

Etnisch profileren door de overheden mag zich helaas verheugen in een wereldwijde belangstelling. De eerste associatie is die met het politieoptreden waarbij huidskleur een essentiële rol heeft gespeeld bij de selectie van burgers. Mede als gevolg van (inter)nationale incidenten die veel media-aandacht kregen - de rellen in Ferguson in 2014 na de dood van zwarte tiener Michael Brown, de staandehouding van Nederlandse rapper Typhoon in 2016 en de grootschalige internationale Black Lives Matter-protesten in 2020 na de dood van George Floyd, gecombineerd met een actieve lobby van verschillende mensenrechtenorganisaties, is de kennis over en het bewustzijn van deze problematische politiepraktijk gegroeid. Verschillende internationale en regionale organisaties proberen door aanbevelingen en actieplannen het etnisch profileren door rechtshandhavers een halt toe te roepen. ${ }^{1} \mathrm{Als}$ naar de Nederlandse situatie wordt gekeken, blijkt het probleem zich niet te beperken tot de politie. Serieuze problemen doen zich ook voor bij de controle van de rechtmatigheid van fiscale toeslagen en het opsporen van uitkeringsfraude. ${ }^{2}$ In deze bijdrage willen wij aandacht vragen voor rassendiscriminatie vanwege het gebruik van profielen door overheidsinstituties in Nederland. Die discriminatie hoeft niet opzettelijk te zijn en kan ook onbewust plaatsvinden. Alle reden om eerst aan te geven wat wij onder etnisch profileren verstaan en het lastige concept van rassendiscriminatie juridisch te duiden (paragraaf 2). Om deze begrippen nader te illustreren worden vervolgens een aantal markante Nederlandse voorbeelden besproken die in media aandacht hebben gekregen (paragraaf 3). Hoe wordt in Nederland het debat over etnisch profileren het afgelopen decennium gevoerd en welke oplossingsstrategieën worden er voorgesteld? Deze vraag komt in paragraaf 4 aan de orde. Het lijkt erop dat onze anti-discriminatiewetgeving op zich goed op orde is en dat roep de vraag op of er juridische verfijning nodig is of dat naar oplossingen buiten de juridische sfeer moeten worden gezocht (paragraaf 5). Wij denken dat die laatste strategie van belang is omdat de aansturing van de instituties niet door de uitvoeringsambtenaren plaatsvindt, maar door het verantwoor-

1 UN Committee on the Elimination of Racial Discrimination, General Recommendation 36, Preventing and Combating Racial Profiling by Law Enforcement Officials 24 November 2020; en European Commission, A Union of Equality: EU anti-racism action plan 2020-2025, Brussels 18 September 2020, $\operatorname{COM}(2020) 565$ final, para 2.2.

2 Zie P.R. Rodrigues, Themacontrole bijstand discriminatoir? Annotatie bij HR 15 juni 2021 in dit nummer. 
delijke bestuur. Het is zo zeer niet de individuele uitvoerder die moet worden aangesproken, maar eerder het bestuur dat dient te zorgen voor een discriminatievrij werkklimaat (paragraaf 6). We sluiten in deze paragraaf tevens af met suggesties voor een meer holistische oplossingsrichting.

\section{Rassendiscriminatie}

In Aanbeveling 36 van het comité ${ }^{3}$ (CERD) dat toeziet op het VN-verdrag inzake de uitbanning van alle vormen van rassendiscriminatie (IVUR) wordt gesteld dat er geen universele definitie is van etnisch profileren, maar dat er - verkort weergegeven - vier elementen telkens bij betrokken zijn:

1 rechtshandhavers van de autoriteiten;

2 het ontbreken van een objectieve rechtvaardiging;

3 gebaseerd op een van de volgende kenmerken, ras, huidskleur, afkomst, nationale of etnische herkomst;

4 in het bijzonder toegepast bij migratiecontrole, criminaliteitsbestrijding en antiterrorisme maatregelen.

Hoewel er meer omschrijvingen van etnisch profileren beschikbaar zijn, ${ }^{4}$ volstaat deze adequate omschrijving van het CERD voor het betoog dat in deze bijdrage wordt gevoerd. De omstandigheid dat Aanbeveling 11 van de ECRI dateert uit 2007 en Aanbeveling 36 van het VN-comité uit 2020 geeft al aan dat het probleem van etnisch profileren door rechtshandhavers een hardnekkig maatschappelijk probleem is dat zich slecht laat uitbannen.

Een van de verklaringen is de compliciteit van het concept rassendiscriminatie. Zoals een advocaat-generaal bij de Hoge Raad opmerkte, komt het begrip ras passender voor bij honden of aardappels dan bij mensen. ${ }^{5}$ Maar het juridische begrip ras is bedoeld om etnische discriminatie van personen in regelgeving te kunnen operationaliseren. De grondslag daarvoor ligt in het reeds genoemde IVUR dat uit 1966 stamt. Daarin valt te lezen dat onder ras mede moet worden begrepen huidskleur, afkomst, nationale en etnische afkomst. ${ }^{6}$ Dit verdrag bepaalt dat de verdragstaten het verbod op rassendiscriminatie in hun wetgeving dienen te incorporeren. Het begrip ras wordt daarbij niet zozeer biologisch, maar meer sociologisch ingevuld. Bij de herziening van artikel 429quater van het Wetboek van Strafrecht in 1981 wordt daarover in de memorie van toelichting het volgende opgemerkt: ${ }^{7}$

'Afhankelijk van tijd en plaats zal men voor de vaststelling of er sprake is van discriminatie wegens ras moeten aanknopen bij verschillende kenmerken. Die

3 Zie noot 1.

4 Een veelgebruikte definitie is die van de Europese Commissie tegen Racisme en Intolerantie (ECRI), ECRI General Policy Recommendation No. 11 on Combating Racism and Racial Discrimnation in Policing, 29 June 2007.

5 Overweging 6.2 van de conclusie van A-G Mok bij het Maimonides-arrest, HR 22 januari 1988, NJ 1988, 891, m.nt. E.A. Alkema.

6 Art. 1 lid 1 IVUR.

7 Kamerstukken II 1980/81, 16 115, nr. 5, p. 5. 
kunnen van fysieke, etnische, geografische, culturele, zelfs historische of godsdienstige aard zijn.'

Deze omschrijving brengt mee dat het een dynamisch en complex begrip is. Het is niet altijd eenduidig of er daadwerkelijk sprake is van discriminatie. Rechters blijken er in de praktijk soms ook verschillend over te kunnen oordelen. Zo is er rechtspraak over uitlatingen door een demonstrant waarin 'Arabieren' worden beledigd waarbij de rechtbank en in hoger beroep het hof oordelen dat het geen strafbare discriminatie is, maar na interventie door de Hoge Raad komt het hof op dit oordeel terug. ${ }^{8}$ Als het om overheidsinstituties gaat, zou verwacht mogen worden dat noch in de regelgeving, noch in de uitvoering verboden onderscheid wordt gemaakt. De Toeslagenaffaire bij de Belastingdienst, waarbij vooringenomen terugvorderingen zijn doorgevoerd op basis van de tweede nationaliteit van de burgers, laat zien dat die verwachting is gelogenstraft. ${ }^{9}$ Inmiddels heeft de Eerste Kamer op 23 maart 2021 de Parlementaire onderzoekscommissie effectiviteit antidiscriminatiewetgeving (POC) ingesteld. ${ }^{10}$ Het onderzoek ziet met name op de oorzaken van en mogelijke oplossingen voor de kloof tussen de wet op papier en de wet in praktijk als het gaat om discriminatie. Daarbij wordt beoogd duidelijkheid te verkrijgen waar in de keten van wetgeving naar beleid haperingen optreden die burgers raken. De POC richt zich op arbeidsmarkt, onderwijs, sociale zekerheid en politie.

Een tweede complicerende factor is dat het verboden onderscheid zowel directe discriminatie kan betreffen als indirecte. Bij directe discriminatie wordt op een verdachte grond onderscheid gemaakt zonder dat daarvoor een objectieve rechtvaardiging is. Bijvoorbeeld een gekleurde persoon controleren omdat wordt verondersteld dat huidskleur een indicatie voor mogelijke criminaliteit zou zijn. Maar ook als onderscheid gemaakt wordt op grond van een neutraal criterium, kan dat indirect onderscheid naar ras tot gevolg hebben. Bijvoorbeeld als geworven wordt voor gezonde Hollandse jongens om bollen te pellen. Zo heeft de Hoge Raad in het Moelander-arrest aangeven dat bij onderscheid naar het buitenlandse kenteken van de auto door opsporingsambtenaren mogelijk indirect verboden onderscheid naar ras van de bestuurder kan worden gemaakt. ${ }^{11}$

Een laatste complicatie die we willen noemen is de vraag of in overheidsprofielen etniciteit gebruikt mag worden als dat criterium niet alleen of in overwegende mate de doorslag geeft. De Hoge Raad heeft het arrest Dynamische verkeerscontrole daar onduidelijkheid over laten voortbestaan. ${ }^{12}$ Het betrof een proactieve controle (zonder verdenking) vanwege de buurt waar de auto reed, omdat het ver25 oktober 2018, ECLI:NL:GHAMS:2018:3942.

9 Zie hierover het rapport Ongekend onrecht van de Parlementaire ondervragingscommissie Kinderopvangtoeslag, www.tweedekamer.nl/sites/default/files/atoms/files/20201217_eindverslag_ parlementaire_ondervragingscommissie_kinderopvangtoeslag.pdf.

10 www.eerstekamer.nl/commissies/poc.

11 P.R. Rodrigues (2019). Is controle van voertuigen uit Midden en Oost-Europa discriminatoir? Annotatie bij HR 9 oktober 2018, ECLI:NL:HR:2018:1872. Crimmigratie \& Recht 2019, nr. 1, p. 47-49. 
huurbedrijf van de auto connecties met criminelen zou hebben en omdat de bestuurder een Hindoestaans uiterlijk en de bijrijder een Oost-Europees uiterlijk had. De relevantie van deze etnische kenmerken ontbreekt volgens ons en daarnaast mag etniciteit alleen gebruikt worden als daarvoor zeer zwaarwegende redenen zijn aan te voeren. ${ }^{13}$ Maar deze vraag blijft uiterst actueel aangezien Amnesty International, het Nederlands Juristen Comité voor de Mensenrechten, Stichting Radar, Controle Alt Delete en twee burgers de Nederlandse Staat hebben gedagvaard omdat het gebruik van etniciteit bij profielen voor controles na grensoverschrijding door de Koninklijke Marechaussee (Kmar) onrechtmatig zou zijn. De rechtbank Den Haag heeft geoordeeld dat het gebruik van ras in combinatie met andere factoren in beginsel toegestaan is. ${ }^{14} \mathrm{Wij}$ delen die conclusie niet omdat het gebruik van etniciteit als criterium in deze context niet objectief gerechtvaardigd kan worden.

Tot slot nog een opmerking over zowel het institutionele als structurele karakter van het onderscheid naar ras door de overheid. Het blijkt dat het gebruik van dit criterium (direct of indirect) veelal niet incidenteel is, maar dat het uniform wordt toegepast in risicoprofielen. Wanneer daarvan sprake is wordt gesproken van structurele discriminatie. Deze vorm van selectie zal immers niet een toevallige burger treffen, maar structureel vaker burgers met een donkere huidskleur. ${ }^{15}$ Bovendien is het institutionele discriminatie, aangezien het afkomstig is van overheidsinstituties die zich kenmerken doordat zij grote groepen burgers op een gestandaardiseerde wijze benaderen.

\section{Markante voorbeelden}

Het publieke bewustzijn over rassendiscriminatie door handhavers van de overheid is door een aantal in de publiciteit verschenen zaken aanzienlijk toegenomen. Drie in het oog springende gevallen worden hier genoemd.

Op 30 mei 2016 wordt Typhoon staande gehouden in zijn nieuwe auto. De rapper vraagt naar de reden waarop de agent zegt dat de auto niet past bij het profiel van de bestuurder en dat hij dacht dat de auto mogelijk met drugsgeld was gekocht. Later geeft een politiewoordvoerder de volgende uitleg: 'Het gaat om een combinatie van een jonge leeftijd en een splinternieuwe, luxe auto, maar ook zijn huidskleur speelde een rol. ${ }^{16}$ Hier wordt gebruik gemaakt van een profiel met meerdere kenmerken waaronder huidskleur. De vraag is welke indicatie huidskleur oplevert voor het voorkomen en opsporen van criminaliteit. In een diverse samenleving lijkt daarvoor in beginsel geen plaats. De zaak van Typhoon is bijzonder omdat het een zeer bekende en populaire artiest is die een breed en gemêleerd publiek aan

13 P.R. Rodrigues \& M.A.H. van der Woude (2016). Proactieve politiecontrole en onderscheid naar etniciteit of nationaliteit. Nederlands Juristenblad 2016, afl. 32, p. 2294-2302.

14 Rb. Den Haag 22 september 2021, ECLI:NL:RBDHA:2021:10283 en zie de annotatie van P.R. Rodrigues bij deze uitspraak in dit nummer.

15 Dat bleek ook uit het onderzoek naar de controles van de Kmar, M.A.H. van der Woude, J. Brouwer \& T.J.M. Dekkers (2016). Beslissen in Grensgebieden. Den Haag: Boom criminologie.

16 Zie https://nos.nl/op3/collectie/10852/artikel/2150689-typhoon-legt-je-uit-waarom-hij-blij-isdat-hij-staande-werd-gehouden. 
zich bindt. Hij reageert niet gekwetst op de staandehouding, maar gebruikt het om het etnisch profileren aan de kaak te stellen en het debat daarover met de autoriteiten te voeren. Eerder deed Amnesty International met haar rapport over etnisch profileren uit $2013^{17}$ een goede aanzet om de discussie hierover op gang te brengen en de publieke discussie over de casus van deze alom gewaardeerde popster werkt als een stevige katalysator. In 2016 start de politie met het meerjarige programma 'De kracht van het verschil' dat heeft geresulteerd in een 'Handelingskader proactief controleren' waarin de professionele norm van objectiviteit wordt beschreven die door dienders in acht moet worden genomen. ${ }^{18}$ Dat zijn belangrijke stappen, maar ze hebben de klachten over etnisch profileren nog niet doen verstommen. ${ }^{19}$ Een eerste kanttekening is dat de maatregelen zich vooral richten op de uitvoeringsambtenaren en veel minder op de leidinggevenden en degenen die verantwoordelijk zijn voor een objectieve beroepsuitoefening binnen het politiekorps. Een tweede kanttekening is dat de discussie zich vooral heeft gericht op de politie, terwijl de problemen zich ook op andere terreinen voordoen.

Dat het etnisch profileren zich niet beperkt tot de politie kan geilllustreerd worden door de Toeslagenaffaire. Het is een van de ernstigste voorbeelden die al tijden het nieuws bepaalt en tot het aftreden van het kabinet-Rutte III heeft geleid. Met name gekleurde burgers zijn op oneigenlijke en discriminatoire gronden getroffen door onrechtmatige terugvorderingen van kinderopvangtoeslagen door de Belastingdienst wegens vermeende fraude. Daarnaast is gebruik gemaakt van een (te) rigide en zeer streng regime van terugvorderingen die bij kleine fouten verplichtte tot volledige terugvordering. Deze affaire krijgt sinds 2017 in toenemende mate aandacht en naar schatting betreft het 26.000 ouders en daarmee ongeveer 70.000 kinderen. De Parlementaire ondervragingscommissie Kinderopvangtoeslag constateert dat bij de uitvoering van de kinderopvangtoeslag grondbeginselen van de rechtsstaat zijn geschonden. Dit verwijt treft niet alleen de uitvoering - specifiek de Belastingdienst - maar ook de wetgever en de rechtspraak. ${ }^{20}$ Veel van de gedupeerde ouders raakten hierdoor in de schulden, die soms konden oplopen van tienduizenden tot zelfs honderdduizenden euro's. Dat heeft bij veel gezinnen geleid tot ernstige ontwrichting van hun leven doordat ze hun huis of baan kwijtraakten, relaties erop stukliepen, kinderen uit huis werden geplaatst, met alle mogelijke psychische problemen als gevolg. In 2013 werd misbruik van fiscale toelagen ontdekt door een groep Bulgaren. Als reactie daarop introduceert de fiscus strenge regels en wordt onder andere extra controle ingevoerd bij rechthebbenden met een tweede nationaliteit. Het gebruik daarvan is door de Autoriteit Persoonsgegevens als onrechtmatig en discriminerend beoordeeld, alsmede in strijd met de Algemene

17 Amnesty International (2013). Proactief politieoptreden vormt risico voor mensenrechten. Geraadpleegd via www.amnesty.nl/content/uploads/2016/11/rapport_etnisch_profileren_ainl_28_okt_2013. pdf?x71839.

18 Kamerstukken II 2019/20, 30 950, nr. 183. Het Handelingskader is van 27 oktober 2017.

19 Zie ook het vergelijkende onderzoek naar ervaringen van burgers in de EU, Your Rights Matter: Police Stops, Fundamental Rights Agency: Wenen 2021, https://fra.europa.eu/en/publication/2021/ fundamental-rights-survey-police-stops. 
verordening gegevensbescherming. ${ }^{21}$ Inmiddels heeft de Belastingdienst het gebruik van de tweede nationaliteit uit risicomodellen en selectieregels verwijderd, ook buiten de sector van fiscale toeslagen. ${ }^{22}$ Dit gebeurt in 2019, terwijl de Basisregistratie Personen sinds 2015 de tweede nationaliteit al niet meer registreert en deze gegevens sindsdien ook niet meer versterkt aan derden. Het ongekende onrecht treft in de eerste plaats de onschuldige ouders wier levens zeer ernstige zijn beschadigd. Daarnaast treden achtereenvolgens af de staatssecretaris van Financien, Menno Snel in 2019 en de minister van Economische Zaken en Klimaat, Eric Wiebes in 2021, waarna op 15 januari 2021 het voltallige kabinet-Rutte III zijn ontslag indient. Het fraudebeleid is doorgeschoten en dat geldt niet alleen voor de kinderopvangtoeslag, maar ook voor andere toeslagen. Hier willen wij vooral aandacht vragen voor het feit dat bij fraudebestrijding associaties zijn geweest met bepaalde etnische groepen en dat daarom de extra controle en voorbarige verdenking uitging naar personen met een tweede nationaliteit. Het is goed dat deze affaire tot nadenken bij de overheid heeft gestemd en op herbezinning van het gebruik van etnische profielen. Ook de bestuursrechters van de rechtbanken hebben zich de kritiek van de Parlementaire ondervragingscommissie Kinderopvangtoeslag aangetrokken. Zij hebben hun eigen rechtspraak onderzocht op de vraag waarom zij de slachtoffers niet beter hebben beschermd en concluderen dat zij daarin tekort zijn geschoten. ${ }^{23}$

Een belangrijke rechtszaak in het debat over etnische profileren door de overheid is de uitspraak van de rechtbank Den Haag van 22 september $2021 .{ }^{24}$ Het betreft de eerdergenoemde zaak over controles na grensoverschrijding door de Kmar, het zogenoemde Mobiel Toezicht Veiligheid (MTV). De uitspraak van de rechtbank is elders in dit blad van commentaar voorzien en is van belang voor de vraag of ras een criterium voor staandehouding mag zijn als het gebruikt wordt in combinatie met andere kenmerken. Daarbij moet in herinnering worden geroepen dat ook indirect onderscheid verboden kan zijn en bijvoorbeeld selectie op nationaliteit of kentekenplaat kan leiden tot rassendiscriminatie. Hoewel er al langer het vermoeden van etnisch profileren door de Kmar bij MTV bestond, is dit met name aan het licht gekomen door een omvangrijk participerend onderzoek, gepubliceerd in 2016 getiteld 'Beslissen in grensgebieden' ${ }^{25}$ Hoewel dit rapport en de daarop volgende publicaties - waaronder twee proefschriften ${ }^{26}$ - de nodige aandacht hebben gekregen bij alle betrokken actoren, is de praktijk van etnisch profileren bij de Kmar geen

21 Autoriteit Persoonsgegevens (2020, 16 juli). De verwerking van de nationaliteit van aanvragers van kinderopvangtoeslag, Onderzoeksrapport z2018-22445.

22 Kamerstukken II 2019/20, 31 066, nr. 637.

23 Rapport werkgroep reflectie Toeslagenaffaire rechtbanken, Recht vinden bij de Rechtbank, Raad voor de Rechtspraak: Den Haag oktober 2021.

24 Zie noot 14

25 Zie noot 15.

26 T.J.M. Dekkers, Mobility, Control and Technology in Border Areas, Discretion and Decision-making in the Information Age, Leiden: 2019, J. Brouwer, Detection, Detention, Deportation, Criminal justice and migration control through the lens of crimmigration, Eleven: Den Haag: 2020. 
halt toegeroepen. ${ }^{27} \mathrm{Wij}$ vragen ons ernstig af of de maatschappelijke schade in de vorm van een tweedeling die door deze praktijk wordt veroorzaakt wel voldoende door de Kmar wordt meegewogen. En hoewel ook het rendement ervan ter discussie staat, ${ }^{28}$ blijkt er in de uitvoeringspraktijk aanzienlijk belang aan de toepassing te worden gehecht terwijl die praktijk door de leiding wordt onderschreven. Het vonnis van de rechtbank heeft tot een schriftelijke reactie vanuit de Raad van Europa geleid, waarbij vragen aan de ministers van Justitie en Veiligheid, en Binnenlandse Zaken en Koninkrijksrelaties zijn gesteld over deze controversiële praktijk die op gespannen voet staat met het discriminatieverbod. ${ }^{29}$

Het voorkomen van etnisch profileren door de politie heeft in toenemende mate de belangstelling van de minister van Justitie en Veiligheid. ${ }^{30}$ Die aandacht dient dan wel primair naar de korpsleiding en de politiechefs van de regionale eenheden uit te gaan en niet de druk uitsluitend op de dienders te leggen. De politiek heeft op de Toeslagenaffaire onder meer gereageerd met het eerdergenoemde POC-onderzoek en met het instellen per 15 oktober 2021 van een Nationaal Coördinator tegen Discriminatie en Racisme. ${ }^{31}$ Een belangrijke doelstelling van het POC-discriminatieonderzoek is de kloof tussen wetgeving en uitvoering in kaart te brengen. De Toeslagenaffaire en de rechtszaak tegen de Kmar leren ons dat daarvoor niet alleen de wetgever en de overheid zorg moeten dragen, maar dat ook de rechtspraak een belangrijke rol speelt.

\section{Het debat over etnisch profileren}

Het debat over etnisch profileren - en breder, het debat over racisme - is relatief 'jong' in de zin dat racisme en discriminatie vanzelfsprekend altijd thema's zijn geweest die de aandacht hebben gekregen vanuit de (rechts)wetenschap, maar dat het geen thema's zijn die altijd breed maatschappelijk de aandacht hebben gekregen. In deze paragraaf zullen we, beknopt, de ontwikkeling van het debat rondom etnisch profileren en racisme in Nederland schetsen met daarbij bijzondere aandacht voor de centrale focus van het debat in termen van het aanwijzen van (a) oorzaken en (b) oplossingen. Om dit in beeld te brengen hebben we ons gebaseerd op analyse van een veelheid aan nieuwsdocumenten verkregen via de krantendatabase NexisUni (1.758 documenten, via zoekterm ['etnisch profileren' AND 'Nederland']), (beleids)rapportages en wetenschappelijke publicaties. We hebben ons hier beperkt tot discussies over Nederland en rapportages en publicaties gericht op de situatie in Nederland met als tijdsperiode 2000-2021.

Zie onder meer het artikel van P.R. Rodrigues en M.A.H. van der Woude genoemd in noot 13; J.P. van der Leun \& M.A.H. van der Woude (2017). Is dit etnisch profileren? Uit de rij gehaald op het vliegveld, Asiel \& Migratierecht 2017, nr. 6-7, p. 311-314; en A.B. Terlouw (2020). Gebruik van etniciteit in risicoprofielen Marechaussee is discriminatie. Nederlands Juristenblad 2020, afl. 12, p. 833-837.

28 W. Landman \& L. Kleijer-Kool (2016). Boeven vangen: Een onderzoek naar proactief politieoptreden. Politie \& Wetenschap 2016, 194-195.

29 www.eur.nl/en/news/council-europe-extremely-worried-about-ethnic-profiling-dutch-marechaussee.

30 Kamerstukken II 2021/22, 29628 en 28 844, nr. 1035.

31 Kamerbrief van 28 september 2021. 
Het thema etnisch profileren verschijnt - als dusdanig - voor het eerst in het debat in 2009. In dat jaar publiceert het Open Society Institute (OSI), een niet-gouvernementele organisatie die wereldwijd de ontwikkeling van een open samenleving, rechtsstaat en democratisering bevordert, onderzoek naar het gebruik van de stereotypen bij politieoptredens in Nederland, Frankrijk, Duitsland, Italië en andere EU-lidstaten. ${ }^{32}$ Aanleiding voor het onderzoek waren de aanhoudende klachten van Europese minderheids- en migrantengroepen over discriminerende behandeling door politie en justitie. Hoewel in het rapport de nadruk lag op de implicaties van, onder meer, antiterrorismewetgeving en de ruimere bevoegdheden van politie en justitie dientengevolge, op de moslimgemeenschappen in de diverse landen en hun vertrouwen in de overheid, markeert het rapport de voorzichtige start van een bredere maatschappelijke én politieke discussie over etnisch profileren door de overheid en racisme. Dit laatste wordt in 2011 kracht bijgezet wanneer er vanuit de Stichting Nederland Wordt Beter in de vorm van een kunstuiting tijdens de Sinterklaasintocht in Dordrecht door betrokkenen T-shirts worden gedragen met de tekst 'ZWARTE PIET IS RACISME'. ${ }^{33}$

In 2013, publiceert Amnesty International Nederland - geïnspireerd door het OSI rapport - het rapport 'Proactief politieoptreden vormt een risico voor mensenrechten'. ${ }^{34}$ Het rapport heeft een signalerende functie waarbij Amnesty aangeeft dat de Nederlandse overheid al diverse malen op de vingers is getikt door diverse experts en internationale mensenrechtenorganen, waaronder het Mensenrechtencomité van de Verenigde Naties en de Europese Commissie tegen Racisme en Intolerantie (ECRI). Zij roepen de regering op tot grotere inspanningen om etnisch profileren tegen te gaan en om de uitvoering van politietaken te monitoren. ${ }^{35} \mathrm{Met}$ deze aanbevelingen zou de Nederlandse overheid niet of nauwelijks iets hebben gedaan. De observaties en zorgen geuit door Amnesty worden bekrachtigd door de Nationale ombudsman die met betrekking tot de staande politiepraktijken in Den Haag en Amsterdam observeert dat hoewel er geen tot weinig klachten worden ingediend, er wel degelijk aanwijzingen zouden zijn voor etnisch profileren. ${ }^{36}$ De zorgen van de ombudsman worden in 2014 in bredere zin - dus niet slechts beperkt tot de politiepraktijk in Den Haag en/of Amsterdam - bevestigd door het Sociaal Cultureel Planbureau door middel van het rapport 'Ervaren Discriminatie'.

32 Open Society Justice Initiative (2009). Ethnic Profiling in the European Union: Pervasive, Ineffective, and Discriminatory. Voor het laatst geraadpleegd op 21 oktober 2021, via: www.justiceinitiative. org/publications/ethnic-profiling-european-union-pervasive-ineffective-and-discriminatory.

33 Zie hierover: www.nederlandwordtbeter.nl/en/projects/zwarte-piet-is-racism-campaign.

34 Proactief politieoptreden vormt risico voor mensenrechten, Amnesty International: Amsterdam 2013, www.amnesty.nl/content/uploads/2016/11/rapport_etnisch_profileren_ainl_28_okt_2013. pdf?x71839.

35 ECRI (2007) General Policy Recommendation No 11 on Combating racism and racial discrimination in policing; EU FRA (2010) Toward more effective policing. Understanding and Preventing Discriminatory Ethnic Profiling. A Guide; 2013 Report of the Kingdom of the Netherlands, Aruba, Curaçao and St Maarten to the United Nations Committee on the Elimination of Racial Discrimination (CERD), 1 juli 2013.

36 Nationale ombudsman (2014). Contrasterende beelden. Onderzoek naar het optreden van politieambtenaren van Bureau De Heemstraat in de Schilderswijk in Den Haag. Voor het laatst geraadpleegd op 21 oktober 2021, via: www.nationaleombudsman.nl/nieuws/onderzoeken/2014078-contrasterendebeelden. 
Uit het rapport blijkt dat Marokkaanse en Turkse Nederlanders, in het algemeen en dus niet beperkt tot het handelen van de politie, veel vaker discriminatie ervaren dan andere bevolkingsgroepen in Nederland. ${ }^{37}$ Met aanhoudende discussies rondom de figuur van Zwarte Piet en etnisch profileren ferm gepositioneerd op de (internationale) maatschappelijke agenda, wordt 2013 ook wel gemarkeerd als het jaar waarin het racismedebat in Nederland losbarst. ${ }^{38}$ Nederland blijft ook internationaal de aandacht trekken op dit punt. In 2015, het jaar waarin de uit Aruba afkomstige Mitch Henriquez door een nekklem van de Haagse politie om het leven komt, publiceert het $\mathrm{VN}$-comité dat onderzoek doet naar rassendiscriminatie (CERD) een rapport over de Nederlandse situatie. Het comité geeft aan bezorgd te zijn over de toename van discriminatie, inclusief etnisch profileren en stigmatiseren, waarmee mensen van Afrikaanse komaf te maken krijgen. Daarnaast zijn er zorgen over de 'structurele onzichtbaarheid van deze discriminatie' die zou leiden tot bagatellisering van de problematiek. Het beperkte aantal mensen van Afrikaanse komaf in overheidsdienst en het gebrek aan bewustzijn binnen de Nederlandse samenleving over slavernij en het koloniale verleden vindt het comité verontrustend. ${ }^{39}$

Waar er in de eerste jaren van het debat nog voorzichtig wordt omgegaan met het bezigen van terminologie die in maatschappelijke en wetenschappelijke discussies rondom racisme en politiegeweld in de Verenigde Staten wel worden gebezigd, hierbij valt te denken aan termen als institutioneel racisme en expliciete aandacht voor het slavernijverleden, verandert dit gestaag met de tijd en het aanhouden van de debatten. Waar de situatie in de Verenigde Staten aan de ene kant dient als een aanjagende factor in de debatten in Europa, en dus ook in Nederland, is er in beginsel in de Nederlandse debatten veel aandacht voor de verschillen tussen de situatie in beide landen. Zo waarschuwen onderzoekers bijvoorbeeld voor het te snel bezigen van de term 'structureel politieracisme' in de Nederland. Aldus antropoloog en voormalig politieonderzoeker Sinan Çankaya: 'Van Amerika kan je dat zeggen, daar valt per 28 uur een dode door politiegeweld, onder wie disproportioneel veel jonge zwarten. In Nederland zijn er te weinig gewelddadige incidenten om daar harde conclusies aan te kunnen verbinden. Bovendien ontbreekt empirisch onderzoek.' De uitspraak van Çankaya is illustratief voor het wetenschappelijk onderzoek bij aanvang van de discussies rondom etnisch profileren: de aandacht ligt sterk op het verzamelen van empirisch materiaal als bewijs voor etnisch profileren, waarbij onderzoekers lijken te worstelen met het enerzijds niet willen bagatelliseren van ervaringen en percepties van burgers terwijl er anderzijds weinig tot geen onderzoek is dat het perspectief van de politie aan het licht beoogt te brengen. In dit laatste type onderzoek - observaties van de politiepraktijk en de beslissingen van indivi-

37 I. Andriessen, H. Fernee \& K. Wittebrood (2014). Ervaren discriminatie in Nederland. Den Haag: Sociaal en Cultureel Planbureau (SCP).

38 De discussie over racisme moet niet verstommen. (2014, 2 januari). Trouw. Geraadpleegd op 21 oktober 2021.

39 Committee on the Elimination of Racial Discrimination (2015). Concluding observations on the nineteenth to twenty-first periodic reports of the Netherlands (CERD/C/NLD/19-21), 28 August 2015. Zie hierover ook: VN-comité kritisch over discriminatie in Nederland. (2015, 29 augustus). De Volkskrant, Geraadpleegd op 21 oktober 2021. 
duele agenten - wordt in de jaren na het losbarsten van het racismedebat in Nederland dan ook steeds meer geïnvesteerd. ${ }^{40}$

\subsection{De politie als belangrijkste focus binnen het debat rondom etnisch profileren}

De grote aandacht voor onderzoek naar het handelen van de politie is illustratief voor de nadruk die er binnen het debat over etnisch profileren wordt gelegd op het discriminatoire optreden van de politie. Een onderzoek vanuit de Universiteit Leiden naar het mogelijk discriminatoir handelen van strafrechters kreeg weliswaar ook de nodige nationale aandacht, maar zodra de gemoederen daarover waren bedaard, verdween de rechterlijke macht weer snel uit de spotlights van het debat over etnisch profileren. ${ }^{41}$ De sterke focus op de Nationale Politie is te verklaren door het feit dat het handelen van de politie als street level bureaucrats natuurlijk letterlijk het meest zichtbaar en het meest direct voelbaar is voor de samenleving. ${ }^{42}$ Echter, deze focus heeft er onzes inziens ook aan bijgedragen dat etnisch profileren lange tijd louter werd gezien als een probleem van de politie en niet zozeer als een breder, institutioneel, probleem dat - wil het adequaat geadresseerd en bestreden worden - meer holistisch benaderd zou moeten worden. ${ }^{43}$ Zoals in de volgende paragraaf nader uiteengezet zal worden, is het daarbij van cruciaal belang dat er wordt gereflecteerd op de rol van discretionaire ruimte binnen ons rechtsstelsel. Veel van de aangedragen 'oplossingen' voor het probleem van etnisch profileren richten zich ook louter op het handelen van de politie en het daarbinnen introduceren van toezichtsmechanismen. Veel waarde lijkt te worden gehecht aan het, in navolging van Engeland, Frankrijk en Spanje, introduceren van zogenoemde 'stopformulieren': formulieren waarop politieagenten niet alleen hun reden tot het staande houden of aanhouden van een burger moeten verantwoorden, maar waar-

40 Zie onder meer: S. Çankaya (2012). De controle van marsmannetjes en ander schorriemorrie. Het beslissingsproces tijdens proactief politiewerk. Den Haag: Boom Lemma uitgevers; M.A.H. van der Woude \& J.P. van der Leun (2013). De Nederlandse veiligheidscultuur als katalysator voor etnisch profileren. Tijdschrift over Cultuur \& Criminaliteit 2013 (3) 2, p. 123-136; W. Landman \& L. KleijerKool (2016). Boeven vangen. Een onderzoek naar proactief politieoptreden. Politie \& Wetenschap. Twynstra Gudde, via: www.politieenwetenschap.nl/publicatie/politiewetenschap/2016/boevenvangen-279/; J.P. van der Leun, M.A.H. van der Woude, R. Vijverberg, R. Vrijhoef \& A. Leupen (2014). Etnisch profileren in Den Haag? Een verkennend onderzoek naar beslissingen en opvattingen op straat. Boom Lemma uitgevers; P. Musaers (2016). A Public Anthropology of Policing: Law Enforcement and Migrants in the Netherlands, proefschrift Universiteit van Tilburg. Geraadpleegd via: https://research.tilburguniversity.edu/en/publications/a-public-anthropology-of-policing-lawenforcement-and-migrants-in; J.S. Svensson, H. Sollie \& S. Saharso (2012). Proactief handhaven en gelijk behandelen. Reed business; F. Bonnet \& C. Caillault (2015). The invader, the enemy within and they-who-must-not-be-named: how police talk about minorities in Italy, the Netherlands and France. Ethnic and racial studies, 38(7), 1185-1201.

41 H. Wermink, J. de Keijser, \& P. Schuit (2012). Verschillen in straftoemeting in soortgelijke zaken. Een kwantitatief onderzoek naar de rol van specifieke kenmerken van de dader. Nederlands Juristenblad 11/2012, p. 726-733. Zie hierover ook: E. Jorritsma (2015, 30 januari). Het líjkt wel zo, dat rechters discrimineren. NRC Handelsblad.

42 M. Lipsky (2010). Street-level bureaucracy: Dilemmas of the individual in public service. Russell Sage Foundation.

43 Zie voor uitzonderingen: M.A.H. van der Woude, (2017). Chain reactions in criminal justice: discretion and the necessity of interdisciplinary research. Den Haag: Eleven international publishing; S. Brinkhoff (2021) The Dutch paradox 1803 Over discriminatoir handelen in de Nederlandse strafrechtspleging en concrete handvatten om dit tegen te gaan. Nederlands Juristenblad, Afl. 25, p. 2047-2053. 
op ze tevens moeten aangeven wat de etniciteit van de desbetreffende burger is. ${ }^{44}$ Dergelijke formulieren zouden een dubbel succes kunnen hebben: niet alleen zouden ze bijdragen aan het creëren van begrip en inzicht onder dienders dat ze hun handelen niet louter op onderbuikgevoelens maar ook op basis van objectief waarneembare feiten zouden moeten baseren, tevens zouden de formulieren eindelijk licht kunnen schijnen op de oververtegenwoordiging van bepaalde etnische groepen in de politiecijfers, en daarmee dus op discriminatoir handelen door de politie. Dergelijke cijfers worden in ons land immers niet standaard verzameld. Ondanks de eveneens geuite scepsis ten aanzien van de bereidheid van politieambtenaren om dergelijke formulieren in te vullen, laat staan de praktische haalbaarheid en wenselijkheid van het registreren van etniciteit, blijven de formulieren steevast genoemd als een mogelijke oplossing. ${ }^{45}$ In het Verenigd Koninkrijk heeft het stopformulier niet kunnen voorkomen dat minderheden vier keer vaker worden gecontroleerd. ${ }^{46}$ Naast stopformulieren wordt er zowel door de Nationale Politie als door antiracismegroep Controle Alt Delete geïnvesteerd in het creëren van apps waarmee burgers gemakkelijker melding zouden moeten kunnen maken van etnisch profileren. ${ }^{47}$ De apps resulteren slechts in een beperkt aantal meldingen, wat waarschijnlijk te maken heeft met het feit dat, conform bevindingen van de Nationale ombudsman, burgers weinig vertrouwen hebben in het feit dat er daadwerkelijk wat gedaan wordt met hun klacht. ${ }^{48}$ Andere voorstellen gericht op het handelen van, in het bijzonder, politieambtenaren zijn het mee laten lopen van objectieve burgerwaarnemers die de politie kunnen dwingen tot verantwoording, ${ }^{49}$ het om-

44 Deze roep komt vooral vanuit Amnesty International en Controle Alt Delete.

45 Zie onder meer hierover: M. Oostveen (2016, 10 juni). Wij tegen zij. De Volkskrant. Geraadpleegd op 21 oktober 2021.

46 J. Brown, (2021). Police powers: stop and search, Briefing Paper, House of Commons: London, Number 3878, 10 March 2021, p. 22 en zie ook Het stopformulier, Verkenning van de werking van de registratie van staandehoudingen, Pro Facto: Groningen, 20 september 2016.

47 Zie hiervoor onder meer: https://pointer.kro-ncrv.nl/politie-voert-app-in-tegen-etnisch-profilerenmaar-effectiviteit-is-nu-al-twijfelachtig en https://nos.nl/op3/artikel/2150330-app-wil-alle-klachtenvan-etnisch-profileren-verzamelen.

48 Nationale ombudsman. (2021). Verkleurde Beelden. Rapport 2021/03. Via: www.nationaleombudsman. $\mathrm{nl} /$ nieuws/onderzoeken/2021030-verkleurde-beelden. De conclusie ten aanzien van het wantrouwen onder etnische minderheden sluit ook aan bij bevindingen uit de rijke (inter)nationale literatuur naar procedurele rechtvaardigheid. Zie onder meer: M. Schuilenburg, B. Besseling \& F. Uitendaal (2017). Vertrouwen in de politie. Empirisch onderzoek naar de beleving van vertrouwen in de Rotterdamse wijk Bloemhof. Justitiële Verkenningen, 43(4); T.R. Tyler, \& C.J. Wakslak (2004). Profiling and police legitimacy: Procedural justice, attributions of motive, and acceptance of police authority. Criminology, 42(2), 253-282; J. Lee (2017). Of course the cops are racist: Procedural justice, the perception of racial profiling, and citizen satisfaction with law enforcement. Criminology, Crim. Just. L \& Soc'y, 18, 80.

49 A. M'charek (2021, 1 oktober). Etnisch profileren? Doe het niet. NRC Handelsblad.nl. https:// advance-lexis-com.ezproxy.leidenuniv.nl/api/document?collection=news\&id=urn:contentItem:63 RJ-F141-DY4K-82TR-00000-00\&context=1516831. Een reactie vanuit de politie op de voorgestelde burgerwaarnemers: www.parool.nl/amsterdam/politiebonden-eigen-waarnemers-mee-tijdensproef-met-preventief-fouilleren b3dde49e. 
draaien van de bewijslast in geval van etnisch profileren ${ }^{50}$ en het beperken van de discretionaire beslissingsvrijheid van individuele ambtenaren. ${ }^{51}$ De voorgaande uiteenzetting heeft laten zien dat, ondanks zorgen voor racisme in bredere zin, etnisch profileren in Nederland in eerste instantie lijkt te worden gezien als een 'blauw' probleem, een probleem dat speelt binnen de politieorganisatie en waarvoor de oplossingen dan ook moeten worden gezocht op het niveau van de politie en het handelen van de individuele politieambtenaar. Ondanks een met de jaren duidelijker hoorbaar discours rondom institutioneel - of 'systemisch' - racisme, lijkt er pas met de Toeslagenaffaire een breder maatschappelijk besef te ontstaan over de verschillende uitingsvormen van etnisch profileren en de rol die overheidsbeleid hierbij speelt. In de nu volgende paragraaf zullen we aan de hand van het begrip van de 'Dutch paradox' nader reflecteren op de oplossingsrichtingen waarin nu hoofdzakelijk lijkt te zijn gedacht.

\section{De 'Dutch paradox' en de paradox der discretionaire ruimte}

In het rapport naar aanleiding van haar bezoek aan Nederland, merkt de UN Special Rapporteur on contemporary forms of racism, racial discrimination, xenophobia and related intolerance op dat waar de Nederlandse wet- en regelgeving duidelijk is over het verbod op discriminatoir handelen, ook door de overheid, de naleving van deze verboden in de praktijk nogal te wensen over laat. ${ }^{52}$ Sterker nog, het feit dat er een duidelijke wettelijke verankering is, lijkt juist in de weg te staan aan het serieus reageren op en tegengaan van klachten over discriminatoir handelen van uitvoeringsinstanties. Deze tegenstrijdige situatie van het enerzijds - op papier althans - staan voor non-discriminatie en gelijkheid terwijl er anderzijds - in de praktijk - in strijd met deze uitgangspunten wordt gehandeld, wordt door haar de Dutch paradox genoemd. De observaties van de UN Special Rapporteur lijken in te druisen tegen het beeld van Nederland als land van tolerantie en rechtvaardigheid, passend bij onze geschiedenis als gidsland..$^{53}$ Nederland is niet het enige land in Noordwest-Europa waarbij de praktijk van tolerantie af lijkt te wijken van de papieren werkelijkheid en waar het uitgangspunt van non-discriminatie en gelijke be-

50 Dit voorstel komt vanuit de ombudsman die het voorstel als volgt toelicht: 'Een instantie moet uitgaan van het verhaal van de klager - dat neem je als uitgangspunt. Als de klager komt met een verhaal over profilering, ga je niet eerst zeggen "dat kan niet waar zijn".' Volgens de ombudsman worden klachten nu te vaak afgedaan als ongegrond, bijvoorbeeld omdat een ambtenaar zegt zich van geen kwaad bewust te zijn. Zie: https://nos.nl/artikel/2374696-ombudsman-over-etnischprofileren-draai-de-bewijslast-om.

51 J. Koelewijn (2020, 12 juni). Antropoloog Sinan Çankaya: 'De ander uitsluiten doet ook iets met onszelf'. NRC Handelsblad.nl. Geraadpleegd op 21 oktober, 2021.

52 Human Rights Council, 44th session, July 2nd 2020: Report of the Special Rapporteur on contemporary forms of racism, racial discrimination, xenophobia and related intolerance on her visit to the Netherlands. A/HRC/44/57/Add.2

53 J. Herman (2006). The Dutch drive for humanitarianism: Inner origins and development of the gidsland tradition and its external effects. International Journal, 61(4), 859-874. Zie ook: D. van Baar (2015, 11 september). Kom niet aan ons nationale zelfbeeld. De Volkskrant. advance-lexis-com. ezproxy.leidenuniv.nl/api/document?collection=news\&id=urn:contentItem:5GWT-0RY1-JC8WY125-00000-00\&context=1516831. Accessed October 21, 2021. 
handeling niet voor iedereen lijkt te gelden. Onderzoek uit Zweden, Noorwegen en Denemarken - landen die doorgaans ook worden gezien als voorvechters van mensenrechten - laten zien dat ook in die landen tolerantie en rechtvaardigheid niet zijn weggelegd voor eenieder. In het bijzonder waar het gaat om de behandeling van migranten - zowel van binnen als buiten de EU - wijzen academici op de beperkte toepasbaarheid van het dikwijls gelauwerde 'Nordic exceptionalism', waarmee wordt gedoeld op het exceptioneel tolerante en non-repressieve strafrechtelijke klimaat in diverse Scandinavische landen. ${ }^{54}$ Ook in deze landen heeft zich door de steeds grotere focus op risico-uitsluiting en preventie een uitgebreid instrumentarium van preventieve (controle)bevoegdheden ontvouwd die, gevoed door negatieve beeldvorming rondom migratie, de angst voor terrorisme en criminaliteit, in het bijzonder worden toegepast op (jonge) mannen met een migratieachtergrond. ${ }^{55}$ Het bestaan van discretionaire bevoegdheden lijkt aldus een belangrijke rol te spelen bij het ontstaan van de paradoxale situatie in Nederland en Scandinavië voor wat betreft de mate waarin er in de praktijk daadwerkelijk uitvoering wordt gegeven aan non-discriminatie. Dit is op zichzelf geen wereldschokkende observatie: het bestaan van discretionaire ruimte binnen het recht nodigt uitvoeringsambtenaren immers expliciet uit tot het, op basis van de specifieke omstandigheden van het geval en met inachtneming van de eigen professionaliteit, nemen van een beslissing hoe de wet- of regelgeving in een concreet geval moet worden toegepast. De precieze factoren die bij die afweging een rol spelen, worden dikwijls niet gegeven door de wetgever. In het hiernavolgende zullen we eerst nader stil staan bij het concept discretionaire ruimte en de vraag waarom discretionaire bevoegdheden überhaupt in het leven worden geroepen als ze een belangrijke rol lijken te spelen bij discriminatoir handelen door overheidsfunctionarissen.

\subsection{Discretionaire ruimte nader bekeken ${ }^{56}$}

De afgelopen decennia hebben vele rechtswetenschappers, rechtssociologen maar ook veel sociaal wetenschappers waaronder in het bijzonder bestuurskundigen zich over de nadere definiëring van het begrip discretionaire ruimte gebogen. Een

54 K. Franko, M.A.H. van der Woude \& V. Barker (2019). Beacons of Tolerance Dimmed? Migration, Criminalization, and Inhospitality in Welfare States. In: S.K.N. Bendixsen \& T. Wyller (red.), Contested Hospitalities in a Time of Migration: Religious and Secular Counterspaces in the Nordic Region. Religion, Resistance, Hospitalities (RRH): Interpretation, analysis, and documentation (p. 55-75). Abingdon-on-Thames: Routledge.

55 R. Sollund (2006). Racialisation in police stop and search practice - the Norwegian case. Critical criminology, 14(3), 265-292.; D. Wästerfors \& V. Burcar Alm (2020). 'They are harsher to me than to my friend who is blonde'. Police critique among ethnic minority youth in Sweden. Journal of Youth Studies, 23(2), 170-188; R. Sollund (2007). Canteen Banter or Racism: is there a Relationship between Oslo Police's Use of Derogatory Terms and their Attitudes and Conduct towards Ethnic Minorities? Journal of Scandinavian studies in criminology and crime prevention, 8(1), 77-96; R. Solhjell, E. Saarikkomäki, M.B. Haller, D. Wästerfors, \& T. Kolind (2019). 'We are seen as a threat': Police stops of young ethnic minorities in the Nordic countries. Critical Criminology, 27(2), 347-361; Q. Eijkman (2010). Has the Genie Been Let Out of the Bottle-Ethnic Profiling in the Netherlands. Pub. Space: JL \& Soc. Just., 5, 1.

56 Zie voor een uitgebreide uiteenzetting over discretie in recht en samenleving met een focus op het handelen van de politie: M.A.H. van der Woude (2018). Discretie in recht en samenleving. Rechtssociologische reflecties op het gat in de donut. Den Haag: Boom juridisch. 
vaak gehoorde - maar ongelukkige - metafoor om discretionaire ruimte aan te duiden is die van Amerikaanse rechtsfilosoof Dworkin. Dworkin beschrijft discretion als volgt: 'Discretion, like the hole in a doughnut, does not exist except as an area left open by a surrounding belt of restriction. ${ }^{57}$ Evenals het gat in de donut, zou discretionaire ruimte bestaan als gevolg van een daar omheen geconstrueerde beperkende gordel. Waar de beperkende gordel in het geval van de donut het zoete gefrituurde en gesuikerde deeg is, is de gordel in het geval van discretionaire ruimte volgens Dworkin het geheel aan rechtsregels voortvloeiend uit wetgeving en jurisprudentie. De door Dworkin gehanteerde definitie is echter problematisch en lijkt een valse relatie tussen rechtsregels en discretionaire ruimte te suggereren, die in de weg kan staan aan het komen tot effectieve oplossingen voor problemen in te de toepassing van discretionaire bevoegdheden.

Wat deze relatie lijkt te suggereren is namelijk dat discretionaire ruimte aan banden gelegd kan worden door (meer) rechtsregels. Dit is een onjuiste aanname aangezien discretionaire ruimte en (rechts)regels zich niet in een zero sum relatie tot elkaar verhouden in die zin dat hoe meer regels er zijn, hoe minder discretionaire ruimte er zal zijn en andersom. ${ }^{58}$ Discretionaire ruimte is inherent aan elk besluitvormingssysteem en kan zowel ontstaan als een product van de regels - bijvoorbeeld door het gebruik van flexibele open normen - als door hun afwezigheid. ${ }^{59}$ Rechtsregels en discretionaire ruimte zijn dus inderdaad nauw met elkaar verbonden, maar verhouden zich tot elkaar op een meer complexe manier dan de donut metafoor doet voorkomen. ${ }^{60}$ Formeel-wettelijke bepalingen en regels zijn voorts slechts een van de vele ingrediënten waar het deeg van de donut uit bestaat. Beslissingen in concrete gevallen vallen zelden ondubbelzinnig af te leiden uit regels. Regels moeten worden geïnterpreteerd en er moet worden vastgesteld welke regels in een bepaalde situatie al dan niet van toepassing zijn. Discretionaire beslissingen hangen hiermee niet alleen samen met de wettelijke context waarbinnen die beslissing genomen moet worden, maar ook met institutionele en persoonlijke opvattingen over wat 'juist' handelen is. Een voorbeeld van institutionele opvatting is dat de leiding van de Kmar het gebruik van etniciteit bij de uitoefening van MTV toelaatbaar acht, evenals dat de leiding van de fiscus het gebruik van de tweede nationaliteit bij controles heeft geaccordeerd. Deze opvattingen hoeven niet gestoeld te zijn op, en misschien ook helemaal niet aan te sluiten bij, de formeel wettelijke kaders. Hoe uitvoeringsambtenaren regels toepassen en hoe zij hierbinnen tot be-

57 R. Dworkin (1977). Taking rights seriously. London: Duckworth, p. 31.

58 D.J. Spader (1984). Rule of law v. rule of man: The search for the golden zigzag between conflicting fundamental values. Journal of Criminal Justice, 12(4), 379-394.

59 D.J. Galligan (1986). Discretionary Powers. Oxford: OUP.

60 Zie R. Baldwin \& K. Hawkins (1984), Discretionary Justice: Davis Reconsidered. Public Law 57; K. Hawkins (1992a). The Uses of Discretion. Oxford: OUP; K. Hawkins (1992b). The Use of Legal Discretion: Perspectives from Law and Social Science. In: K. Hawkins (1992a), The Uses of Discretion. Oxford: OUP; J. Bell (1992). Discretionary Decision-making: A Jurisprudential View. In: K. Hawkins (ed.), The Uses of Discretion, p. 89-111. Oxford: Clarendon; Schneider, C.E. (1992). Discretion and Rules: A Lawyer's View. In: K. Hawkins (ed.), The Uses of Discretion, p. 47-88. Oxford: Clarendon; J. Black (1997). Rules and Regulators. Oxford: OUP. 
paalde keuzes en beslissingen komen, wordt hiermee aldus slechts gedeeltelijk bepaald door wettelijke normen. ${ }^{61}$

\subsection{Discretionaire paradox?}

Als gevolg van discretionaire ruimte binnen het recht genieten uitvoeringsambtenaren zoals gezegd een zekere keuzevrijheid. Een dergelijke vrijheid gaat, zo moge duidelijk zijn, gepaard met een grote verantwoordelijkheid en met een grote mate van vertrouwen dat er de 'juiste' keuzes gemaakt zullen worden. Kijkende naar literatuur over discretionair beslissen dan lijkt nu juist dat element van vertrouwen problematisch te worden bevonden. De actuele debatten in ons land rondom etnisch profileren door politieambtenaren, zijn in dat opzicht illustratief. Het mogelijk onheuse gebruik is een terecht gesignaleerd risico met grote gevolgen voor de legitimiteit en rechtvaardigheid van overheidsbeslissingen en voor hen die daar het slachtoffer van worden. Desondanks moet worden voorkomen dat het beeld ontstaat dat het louter een individuele uitvoeringskwestie is die kan worden ondervangen door het - middels nadere regelgeving - zoveel mogelijk aan banden leggen van de autonome beslisruimte.

Niet alleen is dit fictie omdat meer regels zoals gezegd geenszins automatisch zullen leiden tot minder discretionaire ruimte, tevens is het bestaan van discretionaire ruimte binnen het recht noodzakelijk met het oog op diezelfde rechtvaardigheid die wordt aangetast in het geval van misbruik. ${ }^{62}$ Volgens Davis (1969:3) moet discretionaire ruimte worden gezien als 'the principal source of creativeness in government and law' ${ }^{63}$ Die creativiteit is nodig en ook wenselijk omdat uitvoeringsfunctionarissen op die manier de mogelijkheid hebben om de ongewenste gevolgen van het toepassen van wet- en regelgeving in individuele gevallen te beperken en om in te kunnen spelen op maatschappelijke en sociale veranderingen. ${ }^{64}$ Kortom, discretionaire ruimte an sich is onvermijdelijk maar ook wenselijk en, even zozeer als regelgeving, zelfs noodzakelijk voor het rechtvaardig en efficiënt laten functioneren van rechtssystemen. Wat de optimale balans is tussen de twee is moeilijk te zeggen en zal wellicht in tijd en per omstandigheid en ook per rechtsgebied of rechtssysteem verschillen. Wat echter met zekerheid te zeggen is, is dat de Dutch paradox ook een paradox van discretionaire ruimte is.

61 M. Lipsky (2010). Street-level bureaucracy: Dilemmas of the individual in public service. Russell Sage Foundation; K. Hawkins (1992a). The Uses of Discretion. Oxford: OUP; K. Hawkins (1992b). The Use of Legal Discretion: Perspectives from Law and Social Science. In: K. Hawkins (1992a), The Uses of Discretion. Oxford: OUP; D.J. Galligan (1986). Discretionary Powers. Oxford: OUP; J. Black (2001). Managing discretion. Unpublished manuscript. London School of Economics. R. Baldwin (1990). Why Rules Don't Work. The Modern Law Review, 53(3), 321-337.

62 D.J. Galligan (1990). Discretionary powers: A legal study of official discretion. Oxford University Press on Demand.

63 K.C. Davis (1969). Discretionary Justice. Baton Rouge: Louisiana State University Press, p. 3.

64 C.E. Schneider (1992). Discretion and Rules: A Lawyer's View. In: K. Hawkins (ed.), The Uses of Discretion, p. 47-88. Oxford: Clarendon. 


\section{Terug naar de discussie over etnisch profileren}

Wat betekent deze uiteenzetting over het bestaan van discretionaire ruimte nou voor het debat over etnisch profileren? Zoals betoogd kunnen controlebevoegdheden zoals verkeerscontroles, preventief fouilleren, MTV en fraudeonderzoek in sociale zekerheid of bij de belastingen worden aangewezen als belangrijke bron voor onheus, discriminatoir overheidsoptreden. Echter, zoals hiervoor betoogd, discretionaire ruimte is ook noodzakelijk voor het efficiënt en rechtvaardig kunnen functioneren van rechtssystemen. Deze observatie sluit de soms gehoorde oplossing van het compleet afschaffen van discretionaire bevoegdheden als de hiervoor genoemde, uit. De wetgever zal, met andere woorden, altijd de mogelijkheid moeten hebben om discretionaire beslisruimte te laten aan uitvoeringsambtenaren. Een tweede observatie die volgt uit het bovenstaande is dat het introduceren van regels ter structurering of invulling van de discretionaire beslisruimte - en dat kunnen formeel-wettelijke regels zijn maar ook beleidsregels op organisatorisch niveau niet per definitie zal leiden tot een inperking van de discretionaire beslisruimte.

Om gevolgen en processen voortkomend uit discretionair handelen en beslissen te begrijpen en adequaat het hoofd te bieden, is het van belang dat er met een meer holistische, een meer alomvattende, visie naar dergelijke kwesties wordt gekeken. Hoewel burgers door middel van het handelen van street level bureaucrats het meest direct in aanraking komen met de discretionaire bevoegdheden en de effecten daarvan, moet dit handelen worden geplaatst binnen en worden bezien in interactie met het grotere geheel waarbinnen deze handelingen vorm krijgen. Waar het geschreven formele recht binnen dit grotere geheel onmiskenbaar een belangrijke factor is, spelen hiernaast ook informele regels en opvattingen over de eigen taakstelling een rol. Opvattingen die op hun beurt weer kunnen zijn ingegeven door verwachtingen, richtlijnen, prestatieafspraken en belangenafwegingen op organisatorisch en politiek of beleidsniveau. Tevens moeten de binnen de samenleving heersende verwachtingen ten opzichte van het recht en zij die het recht moeten toepassen niet uit het oog worden verloren. Niet in de laatste plaats omdat die publieke opinie een belangrijke invloed heeft op het beleid, maar ook omdat die publieke perceptie de interacties met betrokken functionarissen kan beïnvloeden en in het slechtste geval bemoeilijken. Tot slot moet ook de persoonlijke context, de intellectuele en persoonlijke bagage en daaruit voortvloeiende unieke morele blauwdruk waarmee een uitvoeringsambtenaar zijn of haar taak vervult niet worden vergeten.

Daarnaast noopt een holistisch perspectief tot het inzicht dat vraagstukken - en daarmee dus ook problemen - rondom discretionaire beslissingen onderdeel uitmaken van een reeks van beslissingen en dat deze plaatsvinden binnen een netwerk van actoren binnen rechtssystemen die allemaal met elkaar in verband staan. ${ }^{65}$ Wat er voor de buitenwereld uitziet als een simpele discretionaire beslissing is in werkelijkheid vaak slechts een onderdeel van een complex netwerk aan

65 R.M. Emerson (1983). Holistic Effects in Social Control Decision Making. Law \& Society Review, 17, 425; R.M. Emerson \& B. Paley (1992). Organizational horizons and complaint filing. In: K. Hawkins (ed.), The Uses of Discretion. Oxford: Clarendon Press. 
beslissingen. Het is dan ook van belang om de interactie tussen verschillende actoren binnen een rechtsstelsel of een rechtssysteem - of het nu gaat over het strafrecht, het ondernemingsrecht, het bestuursrecht of welk rechtsgebied dan ook - te onderkennen: Wat 'output' is voor de ene actor, dient als 'input' voor de andere. Reitz spreekt in deze context over een 'hydraulic displacement of discretion between actors'. ${ }^{66}$

Het belang en de invloed van deze factoren en actoren en de interacties daartussen op wat voor de buitenwereld een simpele, op zichzelf staande beslissing lijkt, kan niet anders aan het licht komen dan via gedegen, theoretisch gefundeerd en empirisch onderzoek waarbij - afhankelijk van de specifiek voorliggende vraag - geput wordt uit de beschikbare variëteit aan kwalitatieve en kwantitatieve onderzoeksmethoden. Met onze oproep tot een meer holistische benadering van discretionair handelen willen we geenszins impliceren dat onheuse beslissingen van uitvoeringsambtenaren op deze manier gedisculpeerd kunnen worden, maar wel dat er in het zoeken naar structurele oplossingen misschien niet louter - of zelfs helemaal niet - moeten worden gegrepen naar meer regels en (bureaucratische) procedures. Misstanden als détournement de pouvoir en etnisch profileren zijn voorbeelden van zogenaamde wicked problems: niet alleen omdat discretionaire ruimte inherent is aan het recht, maar ook omdat de mogelijke problemen die daar uit voortkomen - in het bijzonder een probleem als etnisch profileren - hun wortels kunnen vinden in een kluwen van tegenstrijdige maar nauw met elkaar in verband staande politieke, maatschappelijke, sociale, organisatorische en persoonlijke processen, beslissingen en verwachtingen. Wicked problems zijn daarmee symptomen van dieperliggende, complexe, maatschappelijke problemen en sensitiviteiten.

Zo is het goed dat de politie een Handelingskader heeft opgesteld voor proactief optreden, maar de implementatie daarvan stopt niet bij het afkondigen van dit document. ${ }^{67}$ Het is een verduidelijking van de norm die bij de uitvoering dient te worden gehanteerd, maar het zal alleen succesvol zijn als de aspirant-agenten daarover tijdens de opleiding worden geïnstrueerd. Voor de reeds opgeleide korpsleden dient op dit punt nascholing te worden aangeboden, bijvoorbeeld in de vorm van een training. Daarbij dient te worden gememoreerd dat die uitvoeringsambtenaren in hun handelen sterk beïnvloed worden door de instituties waar zij deel van uit maken. Indien het werkklimaat op dit punt niet vrij van discriminatie is en de leiding daarop niet of onvoldoende toeziet, kunnen misstanden in de uitvoering al snel voorkomen.

Het pleidooi voor meer juridische duidelijkheid over de toelaatbaarheid van etnische kenmerken bij het gebruik van profielen onderschrijven wij. ${ }^{68} \mathrm{Bij}$ controlebevoegdheden zonder verdenking denken wij dat slechts in uitzonderlijke gevallen er op basis van een daderprofiel tijdelijk, gebiedsgebonden en gemotiveerd gecontroleerd mag worden. Zolang de wetgever daarover geen uitsluitsel biedt en de rechtspraak nog niet uitgekristalliseerd is, past terughoudendheid gezien het vereiste

68 Debat over etnisch profileren vraagt om meer juridische duidelijkheid, College Rechten voor de Mens: Utrecht, 9 juni 2021. 
dat alleen zeer zwaarwegende redenen onderscheid naar ras of nationaliteit rechtvaardigen.

Maar veel belangrijker is misschien wel de overheidsverantwoordelijkheid voor een samenleving die niemand op etnische kenmerken achterstelt of uitsluit. Zo zien we dat de wetgever aan zelfreflectie doet door middel van het parlementaire onderzoek (POC) en dat de rechtspraak eveneens heeft gereflecteerd op zijn rol in de Toeslagenaffaire. Kortom, het lijkt ons van belang dat de hele keten van wetgevende, uitvoerende en rechtsprekende macht bijdraagt aan een cultuurverandering waarin voor ingesleten en soms onbewuste vooroordelen steeds minder plaats zal zijn. Daarbij is het een gegeven dat met een dergelijke proces van bewustwording en herbezinning enige tijd gemoeid zal zijn. 